\title{
Factors that Influence High School Female Students' Intentions to Pursue Science, Technology, Engineering and Mathematics (STEM) Education in Malaysia
}

\author{
M Sultana Alam ${ }^{1}$, Sadia Sajid ${ }^{1 *}$, Jin Kuan Kok ${ }^{2}$, Mobashar Rahman ${ }^{3}$ \\ and Aamir Amin ${ }^{3}$ \\ ${ }^{1}$ Department of Journalism, Faculty of Arts and Social Science, Universiti Tunku Abdul Rahman (UTAR), \\ 31900, Kampar, Malaysia \\ ${ }^{2}$ Department of Psychology and Counselling, Faculty of Arts and Social Science, \\ Universiti Tunku Abdul Rahman (UTAR), 31900, Kampar, Malaysia \\ ${ }^{3}$ Department of Information Systems, Faculty of Information and Communication Technology, \\ Universiti Tunku Abdul Rahman (UTAR), 31900, Kampar, Malaysia
}

\begin{abstract}
Despite the increase in the number of female students in education indicating a reversal in the gender gap, their participation in Science, Technology, Engineering, and Mathematics (STEM) education in Malaysia is still a matter of concern. This study extends empirical explanations for this gender gap and identifies factors influencing high school students' intentions to pursue Science, Technology, Engineering, and Mathematics (STEM) Education in Malaysia. The present study aims to develop a framework of female intention to pursue STEM education by examining the impact of five independent variables on STEM self-efficacy and in turn the impact of self-efficacy on intention. The independent variables include attitude towards STEM,

ARTICLE INFO

Article history:

Received: 8 October 2020

Accepted: 26 February 2021

Published: 22 June 2021

DOI: https://doi.org/10.47836/pjssh.29.2.06

E-mail addresses:

sultana@utar.edu.my (M Sultana Alam)

Sadiasajid@1utar.my (Sadia Sajid)

kokjk@utar.edu.my (Jin Kuan Kok)

mobashar@utar.edu.my (Mobashar Rahman)

Aamir@utar.edu.my (Aamir Amin)

*Corresponding author self-concept, gender stereotype, motivation, and teacher stereotypes. The study also examines the independent and moderating impact of career outcome expectancy on the relationship between self-efficacy and intention. Data was collected from 211 secondary school female students in Forms 4 and 5, studying at eight secondary schools in two states in Malaysia. The data was analyzed using SmartPLS. The results of
\end{abstract}


the study show that attitude, motivation, and career outcome expectancy are positive and are significant predictors of STEM self-efficacy, whereas gender and teacher stereotypes are the negative predictors. The results of the study also highlight that selfefficacy is a strong predictor of intention to pursue STEM education. These findings of the study would assist policymakers to develop suitable strategies to improve female participation in STEM education in Malaysia.

Keywords: Female, intention, Malaysia, self-efficacy, STEM

\section{INTRODUCTION}

Over the past decade, Science, Technology, Engineering, and Mathematics (STEM) education has received growing attention (Honey et al., 2014). By providing the necessary skills and knowledge, STEM education has laid the technological foundations for a sustainable society (Meng et al., 2014). Hence, the world needs more STEM literate individuals, professionals, and leaders (Ramsey, 2018) and its importance cannot be undermined.

According to a report published by the American Association of University Women (AAUW), an increase in female interest and participation in STEM education may lead to increased innovation as well as competitiveness (AAUW, 2010). The AAUW report further informed that to represent and cater to the needs of female consumers, it is important that the STEM workforce comprises women and men in equal and proportional numbers. Other authors i.e., Chubin et al. (2005) also emphasized the need for a diverse workforce with females. Hence, it can safely be asserted that STEM and women need each other (Ramsey, 2018).

The research has shown an increase in female participation in STEM fields in the past 50 years (Rabenberg, 2013). However, despite its importance and relevance to the $21^{\text {st }}$-century challenges, the dearth of female participation continues and as a result, the gender disparity in STEM education exists all over the world (The Association of Academies and Societies of Sciences in Asia [AASSA], 2014; United Nations Educational, Scientific and Cultural Organization [UNESCO], 2017). Over the years, female students' interests in STEMrelated careers gradually declined, as early as during their studies at the secondary level (Riegle-Crumb et al., 2011). As of 2019 , only $27 \%$ of the STEM workforce in the United States of America (USA), the world leader in science and technology, is comprised of females (Martinez \& Christnacht, 2021). As a result of this gender gap in STEM education, various global, as well as domestic challenges have emerged. For instance, due to their lack of participation in STEM education and careers, the female population tends to have lesser earnings as well as opportunities for leadership positions as compared to males. Moreover, not only for better pay scales or leadership opportunities but females also need to be STEM-literate in order to lead 
an informed and effective life as users of STEM-related products (Ramsey, 2018).

Similarly, in Malaysia, where although female participation in education has improved, the interest of female students in taking up STEM subjects has decreased (Kamsi et al., 2019). Malaysia being a patriarchal society, tends to hinder women from fully utilizing their potential (Azmawati et al., 2017). As women are expected to play a vital role in the family (Abdullah et al., 2008), most of the females choose family over career (Noor, 2001). Hence, there is an under-representation of women in technology and engineering-related STEM fields in Malaysia (Goy et al., 2018).

Some of the factors behind the lack of female participation in STEM fields include those that are related to selfconfidence, education, culture, and society (AAUW, 2010). Due to the importance of female participation in STEM education and careers, this under-representation has been extensively studied across the world (O'Brien et al., 2020). Similarly, in the context of female participation in STEM education in Malaysia, researchers have identified and studied several factors. With regards to individual factors, Pang et al. (2015) who studied the impact of gender, personality types, and pre-school time duration on mathematics achievement, found that the duration of time spent in preschool has a significant impact on mathematics achievement. Halim et al. (2018) who studied further the impact of students' STEM self-efficacy on their career choice in STEM as well as physics found statistically significant and positive relationships between the aforementioned constructs. The study also found that females showed a higher self-efficacy in science, whereas the males showed higher levels of self-efficacy in engineering. Yeoh and Ierardi (2015) who examined the role of motivation of matriculation students in learning biology, studied different kinds of motivation including intrinsic, extrinsic, grade and career motivation, self-determination, and self-efficacy. The result of the research showed that extrinsic motivation and grade motivation surpassed intrinsic motivation for females. The study also indicated that female students possessed a lower level of self-efficacy when compared to males in learning biology. However, the study also indicated that women possess a higher level of self-determination as well as motivation towards achieving high grades and pursuing careers in biology.

In addition to the personal factors, researchers have also identified several key variables which are contextual in nature, and which positively or negatively affect female students' decisions to undertake STEM education or career paths. For example, Abu-Lail et al. (2012) identified the presence of role models as one of the major contextual factors. The authors insisted on the importance of female role models in STEM fields. Goy et al. (2018) further opined that low recruitment at the point of entry in STEM careers is also seen as one of the contextual factors to negatively affect the female decisions to undertake STEM education. In addition, Rajenderan 
and Zawawi (2019) proposed that workfamily stress can affect the psychological well-being of the females working in the Information and Communication Technology (ICT) industry.

However, several other factors have been overlooked or understudied in the Malaysian context such as self-efficacy, stereotyping, intrinsic motivation, personal preferences, self-concept, role model influence, family influence, and low recruitment (Sajid et al., 2020). Hence, the objective of the present research is to examine the impact of the under-studied individual (i.e., self-concept, attitude, motivation, and self-efficacy) and contextual factors (i.e., gender and teacher stereotypes and career outcome expectancy) on female students' intentions to pursue STEM education in Malaysia. Consequently, the present research aims to propose a framework of individual and contextual factors affecting female participation in STEM education in Malaysia.

\section{LITERATURE REVIEW}

Based on the review of the literature, the present study has identified nine factors including self-concept, self-efficacy, attitude, gender-stereotypical norms, motivation, teacher's stereotype as well as career outcome expectancy which may affect female's intention to pursue STEM education at the secondary level of education.

Self-efficacy is an individual's expectation of his/her performance in STEM-related subjects. i.e., "I believe I can get $a B$ in a test of any STEM-related subject". It has been reported that women lack self-efficacy towards STEM-related goals and hence they lose their interest in STEM (Eccles, 1994). Self-efficacy is a strong predictor of the vocational choice of women (Larose et al., 2006), as well as their persistence in STEM education (Lent et al., 2015). While studying the intentions of middle school students in pursuing STEM education, Brown et al. (2016) found a strong relationship between self-efficacy and intention.

The female STEM self-concept is an important factor that can be explained as confidence in her aptitude to accomplish and complete tasks related to STEM through the consolidation and implementation of the required knowledge and expertise to manage STEM-related subjects (Sahranavard \& Hassan, 2012). Self-concept does not reflect achievement in a particular domain (Ertl et al., 2017). According to the studies performed by Marsh and Scalas (2011) and OECD (2015), females were found to be more critical of their STEM-related selfconcept when compared to males. Hence, the STEM-related self-concept may affect the level of achievement in STEM-related subjects (Ertl et al., 2017). Self-concept is similar to self-efficacy, but they differ from each other significantly (Pajares, 2004). STEM self-concept is the general perception of an individual about STEM education, whereas STEM self-efficacy is an individual's expectation about his/ her performance in STEM. For instance, a person might express his STEM selfefficacy in words such as "I believe that I 
can get a $B$ in a test of any STEM-related subject.", whereas, for STEM self-concept, the person might generally say, "I am good at STEM-related subjects" (Rittmayer \& Beier, 2008). Hence, it can be argued that a positive STEM self-concept will lead to positive STEM self-efficacy.

Attitude is one of the important variables in the Theory of Planned Behavior (TPB), and it can be defined as the belief of a person towards the features of some objects (Fishbein \& Ajzen, 1977). In the context of STEM, attitude is defined as the belief, feelings or values held about STEMrelated discipline or its impact on society or the scientists (Osborne et al., 2003). Like self-efficacy, it has been reported that females lack the right attitude towards STEM education (Mahoney, 2010). The attitude of a person towards STEM affects their participation, interest (Greenfield, 1996), and achievement (Papanastasiou \& Zembylas, 2002).

Likewise, gender is a central social construct used by children from preschool years, to compare and categorize and differentiate themselves from others (Renno \& Shutts, 2015). According to Ruble et al. (2007), children as early as 2 years of age can comprehend gender labels, which are reinforced by their interaction with adults (Ruble et al., 2007), and start to form a stereotype (Mulvey et al., 2010) about the different activities, roles, and careers (Blakemore, 2003).

Stereotypes are peculiar to questions such as, who can, should, and is good at STEM education which influences student's intention in STEM education (McGuire et al., 2020). It has been argued that the ability to study, pursue and succeed in the STEM world can be viewed as "gender innate" in the sense that it is meant for men (McGuire et al., 2020). As a result, according to McGuire et al. (2020), female students have to suffer lifelong consequences of these stereotypes for their engagement and motivation in the STEM domain. According to Cundiff et al. (2013) and Schuster and Martiny (2017), these gender stereotypes negatively affect the motivation as well as self-efficacy of women to pursue STEM education or careers. The same was echoed by Garriott et al. (2017) in a study on adults, which showed that gender stereotypes significantly predict STEM self-efficacy, which in turn is a strong predictor of career goals.

Another variable namely motivation entails the degree to which a person is moved to do something (Deci \& Ryan, 2000). According to the Self-Determination Theory proposed by Deci and Ryan (2000), motivation can be further categorized into intrinsic and extrinsic motivation. Student motivation and self-efficacy are intertwined constructs and has long been understood that the two have a strong relationship in the educational context (Husain, 2014). It is argued that after the students are motivated, they tend to regulate their behavior (GarcíaMartín \& García-Sánchez, 2020). Hence, it can be deduced that people with high selfefficacy have high motivation and in turn, the ones with high motivation will also have high self-efficacy. This phenomenon termed as success-cycle by Ackerman (2020), is seen when a highly motivated individual is 
highly likely to achieve goals, which gives him the experience which in turn increases self-efficacy.

Similarly, the teacher plays a significant role in encouraging females to pursue STEM education. The influence of the teacher on the students' interest in STEM education is shown through the instructional practices of the teacher (Swarat et al., 2012) as well as encouraging behavior (Wang \& Eccles, 2012). Their support has been regarded as a crucial variable to augment the learning and interest of students in STEM education (Nugent et al., 2015). According to Gunderson et al. (2012), teachers are one of the factors to transmit negative stereotypes about their lack of math abilities among young girls. In the late $70 \mathrm{~s}$, the studies by Astin (1975) and Leinhardt et al. (1979), have shown that teachers spent more time and attention on the boys than the girls when teaching Mathematics. According to research conducted by Lavy and Sand (2015), female students with such stereotypical teachers had been persuaded to take up lesser high school courses in STEM-related subjects or were unlikely to take STEM subjects as a major or STEM as a career. According to Blair et al. (2005), teacher stereotypes alone can permanently change the "neurobiology of the prefrontal cortex" and as a result permanently change how females and males perceive their STEM abilities. As for its influence on self-efficacy, according to Bandura (1977), like parents, teachers also play a crucial role in developing the self-efficacy of the children and student's STEM self-efficacy is improved when the significance of STEM skills is emphasized by the teachers (Bandura et al., 2001).

Behavioral intention is one of the elements of the Theory of Planned Behavior (TPB). It has been defined by Ajzen (1991) as the willingness of an individual to work hard and try to perform a particular behavior. According to Hardin and Longhurst (2016), women lack a strong intention to pursue STEM education. Hence, this becomes a relevant factor when studying female participation in STEM education. It has been argued that a student's intention to pursue STEM education and goals is affected by self-efficacy and outcome expectations, and the former can be increased by increasing the later factors (Fouad \& Santa, 2017). Hence, the present study hypothesized the impact of self-efficacy and career outcome expectancy on female intention to pursue STEM education.

Outcome expectancy is also one of the important variables in social cognitive theory. It is defined as the "self-perceptions of the anticipated consequences or outcomes that would accrue, if the person were employed in the occupation of her/his choice" (Springer et al., 2001). The career outcome expectations can increase the motivation of the person to pursue a particular career while overcoming the barriers and increasing her competency. Furthermore, Social Cognitive Career Theory (SCCT) elaborates that outcome expectations not only affect self-efficacy, but they can also affect the intention or goals of an individual. 
THEORETICAL FRAMEWORK

Theoretically, the present study is based on two theories the Theory of Planned Behavior (TPB) by (Ajzen, 1991) and Social Cognitive Career Theory (SCCT) by Lent et al. (1994). The Theory of Planned Behavior (TPB), a renowned theory to explain human behavior, posits that intention is the strongest predictor of behavior, where attitude, subjective norms, and perceived behavioral control predict the intention (Ajzen, 1991). According to Moore and Burrus (2019), TPB has predictive power for STEM academic choices. As for the
SCCT, the theory posits that the student's decision to choose a particular career path is an outcome of the interaction between various cognitive and environmental factors as well as explicit behaviors (Ambriz, 2016). TPB and SCCT have been instrumental in explaining planned human behavior and cognitive choice of a career path, respectively. Based on these two theories and the literature review, the proposed framework for the present research work has been illustrated in Figure 1, whereas the proposed hypotheses have been presented in Table 1.

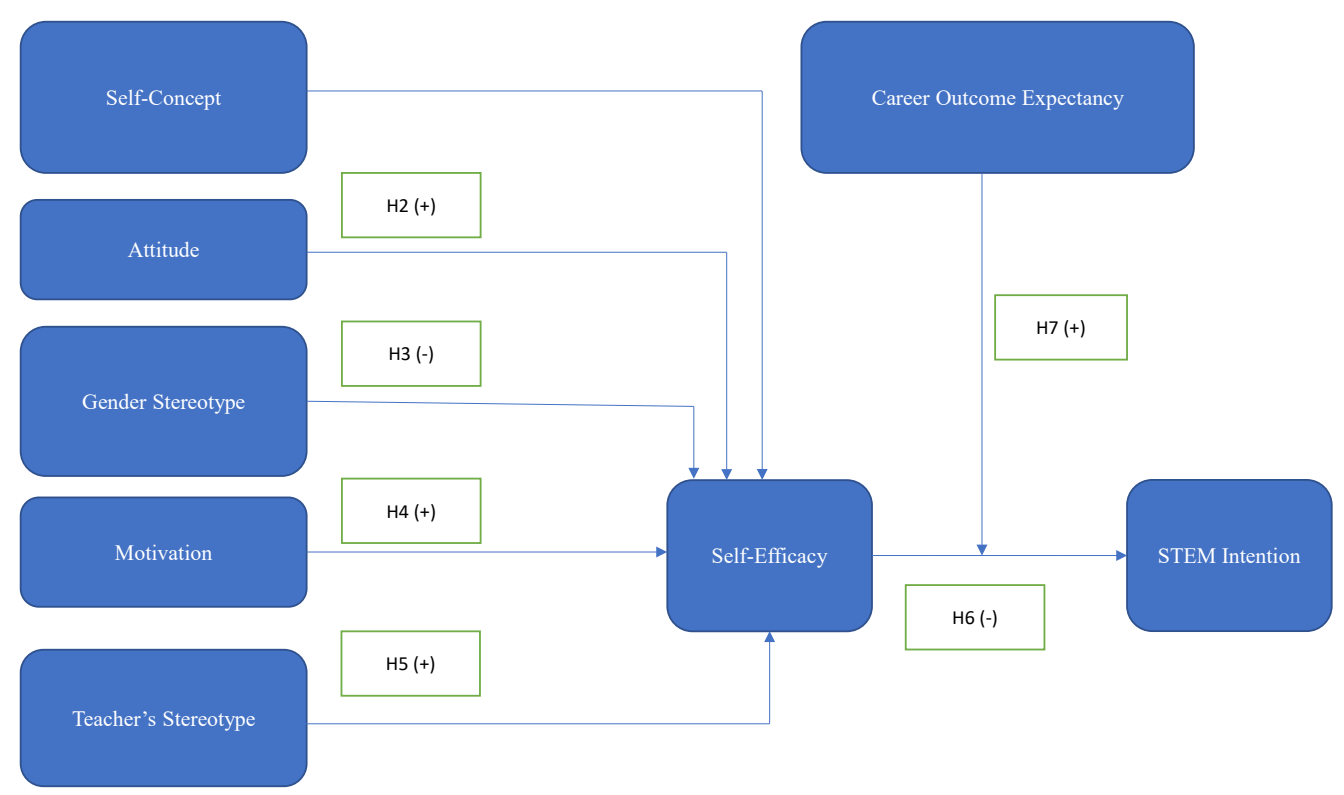

Figure 1. Proposed theoretical framework 
Table 1

Proposed hypotheses

\begin{tabular}{|c|c|}
\hline Hypothesis No. & Hypothesis Statement \\
\hline $\mathrm{H} 1$ & $\begin{array}{l}\text { STEM self-concept will positively affect the STEM self- } \\
\text { efficacy of female students }\end{array}$ \\
\hline $\mathrm{H} 2$ & $\begin{array}{l}\text { Attitude towards STEM will positively affect female STEM } \\
\text { self-efficacy. }\end{array}$ \\
\hline H3 & $\begin{array}{l}\text { STEM-related gender stereotypes will negatively impact female } \\
\text { students' STEM self-efficacy. }\end{array}$ \\
\hline $\mathrm{H} 4$ & $\begin{array}{l}\text { Motivation will positively impact female students' STEM self- } \\
\text { efficacy. }\end{array}$ \\
\hline H5 & $\begin{array}{l}\text { Teacher stereotypes will negatively impact female students' } \\
\text { STEM self-efficacy. }\end{array}$ \\
\hline H6 & $\begin{array}{l}\text { Self-efficacy will positively affect the intention of women to } \\
\text { pursue STEM education }\end{array}$ \\
\hline $\mathrm{H} 7$ & $\begin{array}{l}\text { COE will positively moderate the relationship between female } \\
\text { students' STEM self-efficacy and their intention to pursue } \\
\text { STEM education. }\end{array}$ \\
\hline
\end{tabular}

\section{METHODOLOGY}

The present study is quantitative in nature where the quantitative data was collected through the survey questionnaire. The data was collected from 211 female students studying in Forms 4 and 5 at eight secondary schools in the Klang Valley and Kuala Lumpur. As for the sampling method, a convenience sampling method was employed in this research. The data was gathered using pre-validated scales on a five-point Likert scale. The survey questions were tailored to fit the context of the present research were found necessary. Table 2 highlights the variables, the source from which their instruments were adopted, the number of items, and a sample item from the survey. The complete questionnaire items for each variable as well as the coding are included in Appendix 1.

After collection, the data was analyzed using Smart Partial Least Square (PLS). The data were analyzed in two stages measurement model evaluation followed by structural model evaluation. In the measurement model evaluation, the reliability of the data was analyzed using Cronbach's Alpha and composite reliability, whereas the convergent and discriminant validity was evaluated by using tests such as Average Variance Extracted (AVE) and Forner-Larcker criterion respectively.

In the structural model evaluation, the path coefficients, as well as the significance of the correlation, were assessed through the bootstrapping method. This helped in testing 
Table 2

Adopted scales for all constructs

\begin{tabular}{|c|c|c|c|}
\hline Variable & Source & $\begin{array}{l}\text { No. of } \\
\text { Items }\end{array}$ & Example \\
\hline Self-Concept & Kulm (1973) & 27 & $\begin{array}{l}\text { "How comfortable I feel in STEM } \\
\text { subjects' class" }\end{array}$ \\
\hline Attitude & Mahoney (2010) & 24 & $\begin{array}{c}\text { "I enjoy learning about STEM } \\
\text { subjects" }\end{array}$ \\
\hline $\begin{array}{l}\text { Gender } \\
\text { Stereotype }\end{array}$ & $\begin{array}{l}\text { Maryann and } \\
\text { Patience (2017) }\end{array}$ & 19 & $\begin{array}{l}\text { "Girls are assigned more domestic } \\
\text { duties in the house than boys" }\end{array}$ \\
\hline Motivation & Edzie (2014) & 10 & $\begin{array}{l}\text { "My school counselor encouraged } \\
\text { me to study STEM-related courses" }\end{array}$ \\
\hline $\begin{array}{l}\text { Teacher } \\
\text { stereotype }\end{array}$ & Ertl et al. (2017) & 4 & $\begin{array}{c}\text { "Teachers are more likely to } \\
\text { encourage boys to take STEM } \\
\text { subjects" }\end{array}$ \\
\hline Self-Efficacy & $\begin{array}{l}\text { Jenson et al. } \\
\qquad(2011)\end{array}$ & 7 & $\begin{array}{l}\text { "How confident are you that you } \\
\text { can get good grades in your STEM } \\
\text { courses this semester?" }\end{array}$ \\
\hline Intention & Salleh (2013) & 4 & $\begin{array}{l}\text { "I intend to learn STEM subjects to } \\
\text { gain more scientific knowledge". }\end{array}$ \\
\hline $\begin{array}{l}\text { Career } \\
\text { Outcome } \\
\text { Expectancy }\end{array}$ & $\begin{array}{l}\text { Springer et al. } \\
\qquad(2001)\end{array}$ & 26 & $\begin{array}{c}\text { "I will get a feeling of } \\
\text { accomplishment if I work in STEM } \\
\text { related job" }\end{array}$ \\
\hline
\end{tabular}

the proposed hypotheses of the present research. The results and discussions are presented in the following section.

\section{RESULTS AND DISCUSSION}

\section{Measurement Model Evaluation}

In the measurement model evaluation, construct reliability and validity were examined by using measures such as Cronbach's Alpha, Composite reliability, and Average Variance Extracted (AVE). Table 3 shows the results of the mentioned measures. The discriminant validity results are further illustrated in Table 4 as measured by the Fornell-Larcker criterion. Figure 2 illustrates the measurement model.

The reliability of the survey instrument is measured through Cronbach's Alpha and composite reliability. According to Henseler et al. (2009), .70 and above is considered satisfactory and good reliability of the survey instrument. As for validity, which is measured through Average Variance Extracted (AVE), most of the variables achieve an AVE value of .50 and above which is considered as a satisfactory value (Henseler et al., 2016). 
According to the results presented in Table 3, all the variables measured in the survey have and indicate satisfactory reliability and validity.

For satisfactory discriminant validity, the value of the square root of AVE for each variable should be higher than the correlations among the variables (Fornell \& Larcker, 1981; Henseler et al., 2009). According to the results presented in Table 4, all the variables meet the Fornell-Larcker criteria for discriminant validity.

\section{Structural Model Evaluation}

Table 5 shows the path coefficients and significance values for the relationship between the constructs. Figure 3 illustrates the structural model. The results shown in Table 5 are the outcomes for the structural model evaluation of the present study to examine the factors influencing female participation in STEM education in
Malaysia. The study analyzed the impact of seven independent variables on STEM self-efficacy and in turn its impact on female students' intentions to pursue STEM education. The five independent variables are attitude, gender stereotypes, motivation, self-concept, and teacher stereotypes. The study also examined the impact of career outcome expectancy as a moderating variable.

According to the results, attitude towards STEM (beta: .170: p-value: .047) positively and significantly predicts female students' STEM self-efficacy. Career outcome expectancy (beta: .536: p-value: .000), when tested as an independent variable, further proved to be a positive, strong, and significant predictor of STEMrelated self-efficacy. The results also indicate that motivation is also one of the strong, positive, and significant predictors

Table 3

Construct reliability and validity

\begin{tabular}{lccc}
\hline & $\begin{array}{c}\text { Cronbach's } \\
\text { Alpha }\end{array}$ & $\begin{array}{c}\text { Composite } \\
\text { Reliability }\end{array}$ & $\begin{array}{c}\text { Average Variance } \\
\text { Extracted (AVE) }\end{array}$ \\
\hline Attitude & .885 & .911 & 0.594 \\
Career Outcome Expectancy & .934 & .942 & 0.505 \\
Gender Stereotype & .771 & .835 & 0.504 \\
Motivation & .863 & .907 & 0.709 \\
STEM Intention & .888 & .923 & 0.750 \\
Self-Concept & .738 & .835 & 0.560 \\
Self-Efficacy & .887 & .914 & 0.639 \\
Teacher stereotype & .880 & .923 & 0.804 \\
\hline
\end{tabular}


What Drives Girls' Intention to Pursue STEM Education in Malaysia?

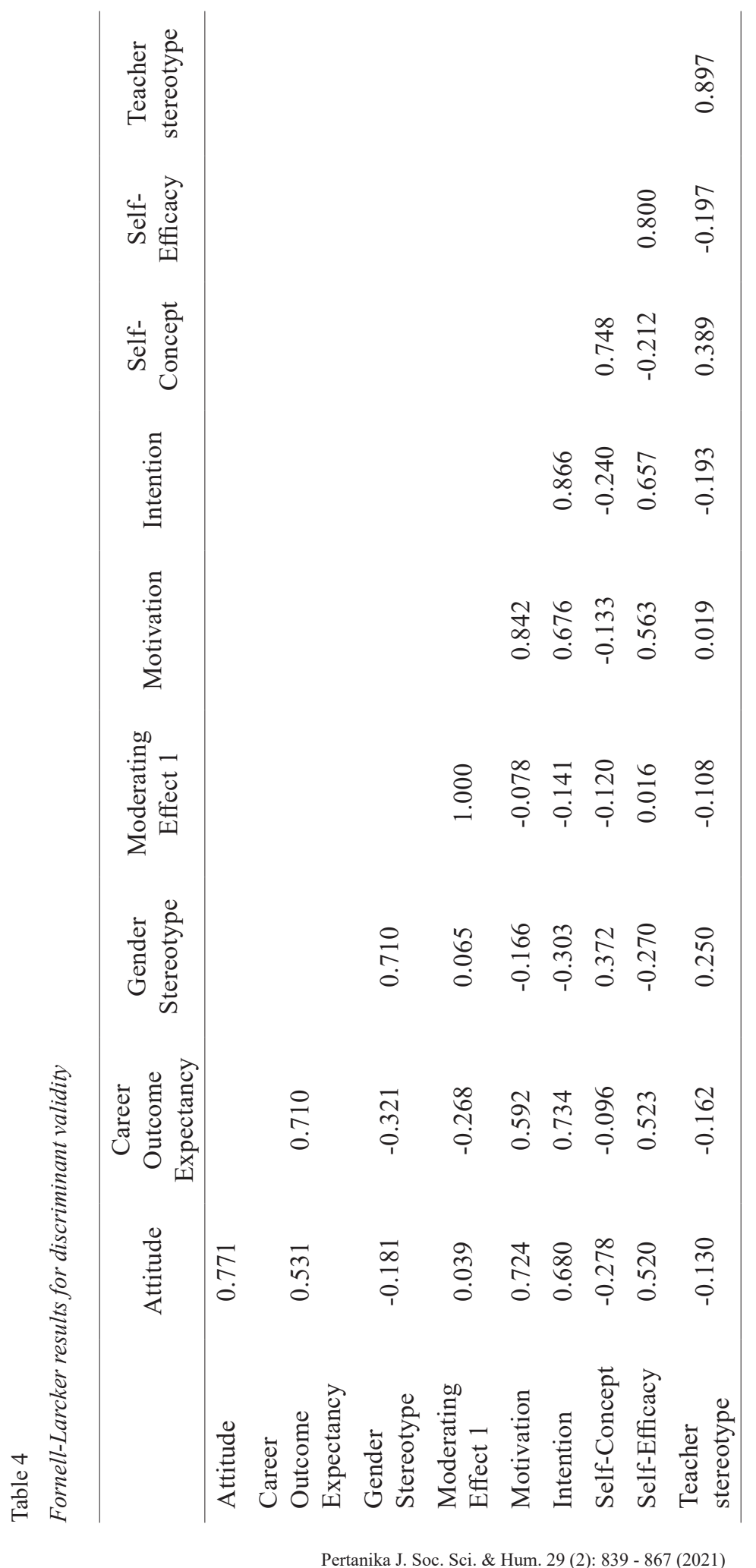


M Sultana Alam, Sadia Sajid, Jin Kuan Kok, Mobashar Rahman and Aamir Amin

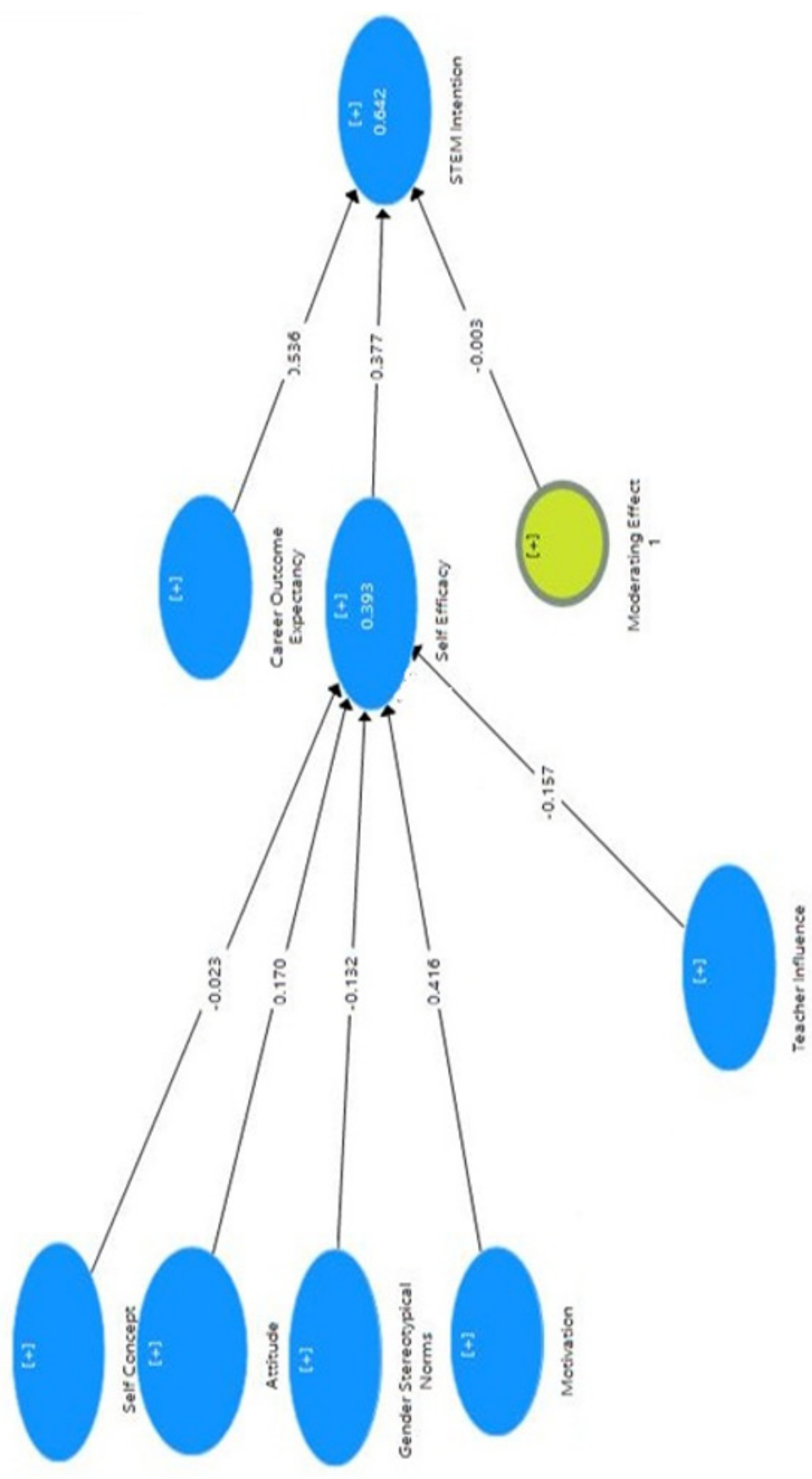

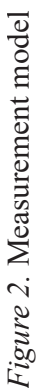


of STEM self-efficacy (beta: .416: p-value: It entails that general gender stereotypes, as $.000)$. In addition, the results also showed that self-efficacy positively, strongly, and significantly predicts intentions to pursue STEM education (beta: .377: p-value: .000).

The present study also found some negative predictors of female self-efficacy. According to the results, gender stereotypes well as teacher stereotypes towards female STEM education, may negatively influence female students' self-efficacy towards STEM education.

Apart from the mentioned relationships, the other relationships proposed in this research did not achieve statistical (beta: -.132: p-value: .054), as well as teacher significance. This includes self-concept stereotypes (beta: -.0157: p-value: .021) (beta: -.023: p-value: .766) and career negatively predicted the self-efficacy of outcome expectancy as moderator (beta: female students to pursue STEM education. -.003: p-value: .914).

Table 5

Path coefficients and significance values

\begin{tabular}{lccccc}
\hline Paths & $\begin{array}{c}\text { Original } \\
\text { Sample } \\
(\mathrm{O})\end{array}$ & $\begin{array}{c}\text { Sample } \\
\text { Mean }(\mathrm{M})\end{array}$ & $\begin{array}{c}\text { Standard } \\
\text { Deviation } \\
(\text { STDEV })\end{array}$ & $\begin{array}{c}\text { T Statistics } \\
(\mid \mathrm{O} / \text { STDEV })\end{array}$ & P Values \\
\hline $\begin{array}{l}\text { Attitude } \rightarrow \text { Self } \\
\text { Efficacy }\end{array}$ & 0.170 & 0.175 & 0.086 & 1.987 & .047 \\
$\begin{array}{l}\text { Career Outcome } \\
\text { Expectancy } \rightarrow\end{array}$ & 0.536 & 0.532 & 0.054 & 9.928 & .000 \\
$\begin{array}{l}\text { STEM Intention } \\
\begin{array}{l}\text { Gender } \\
\text { Stereotype } \rightarrow \text { Self }\end{array}\end{array}$ & -0.132 & -0.135 & 0.069 & 1.930 & .054 \\
$\begin{array}{l}\text { Efficacy } \\
\text { Moderating }\end{array}$ & & & & & \\
$\begin{array}{l}\text { Effect } 1 \rightarrow \text { STEM } \\
\text { Intention }\end{array}$ & -0.003 & -0.005 & 0.030 & 0.109 & .914 \\
$\begin{array}{l}\text { Motivation } \rightarrow \text { Self } \\
\text { Efficacy }\end{array}$ & 0.416 & 0.408 & 0.087 & 4.781 & .000 \\
$\begin{array}{l}\text { Self- } \\
\text { Concept } \rightarrow \text { Self }\end{array}$ & -0.023 & -0.023 & 0.077 & 0.297 & .766 \\
$\begin{array}{l}\text { Efficacy } \\
\text { Self- } \\
\text { Efficacy } \rightarrow \text { STEM }\end{array}$ & 0.377 & 0.382 & 0.049 & 7.701 & .000 \\
$\begin{array}{l}\text { Intention } \\
\text { Teacher } \\
\text { stereotype } \rightarrow \text { Self } \\
\text { Efficacy }\end{array}$ & -0.157 & -0.145 & 0.068 & 2.317 & .021 \\
\hline
\end{tabular}




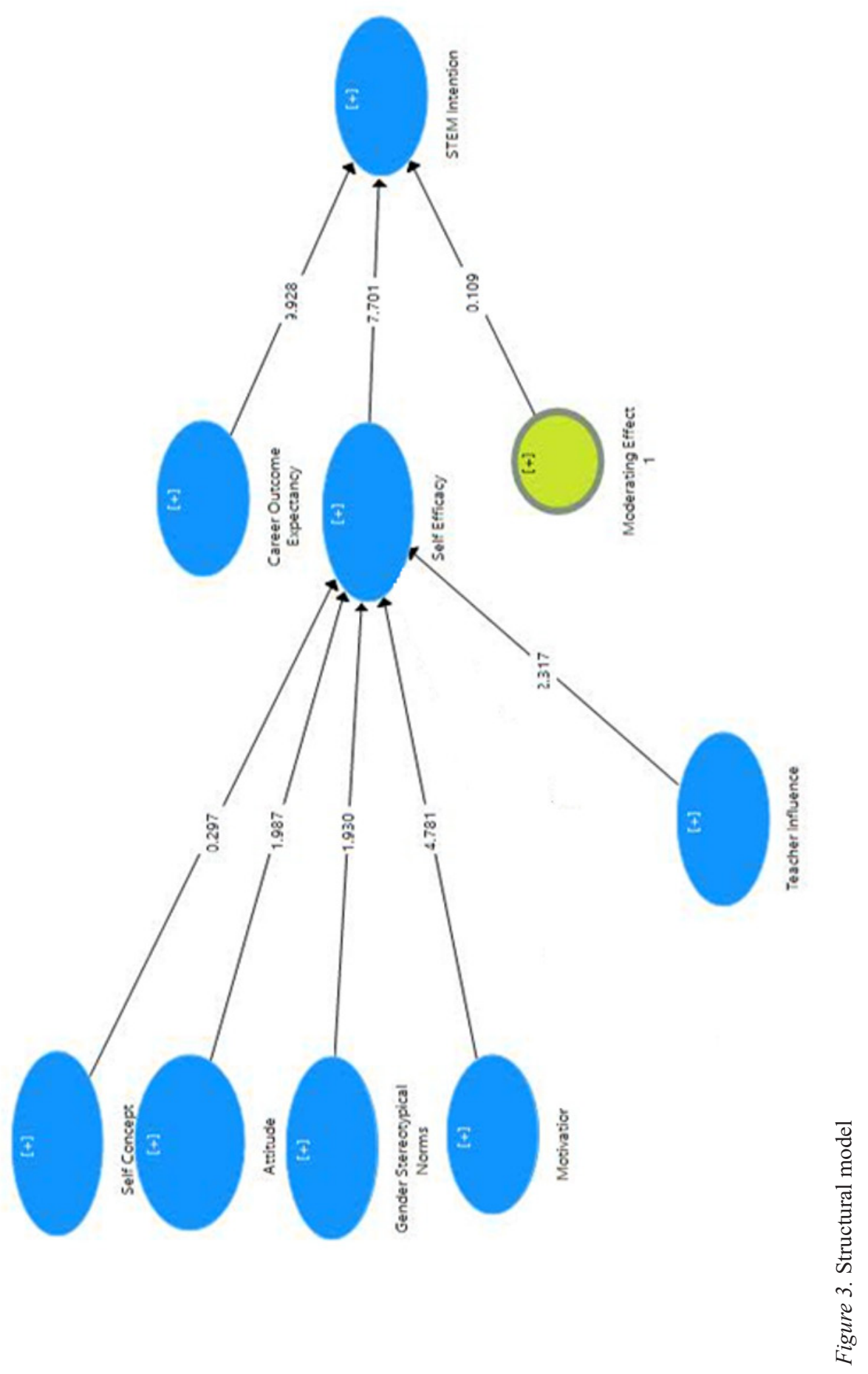




\section{R-Square}

$\mathrm{R}^{2}$ indicates the collective impact of independent variables on the dependent variable. According to Table 6, all the independent variables explain 39.3\% variance in STEM-self efficacy, whereas self-efficacy can predict $64.2 \%$ variance in the intention to pursue STEM. Based on the value of $\mathrm{R}^{2}$, it entails that the percentage of the impact of independent variables on selfefficacy is weak (only 39.3\%), whereas the percentage of the impact of self-efficacy on intention is moderate. It can be ascertained that the variables studied in this study are not holistic in terms of predicting the selfefficacy of female students.

Table 6

$R$ Square value

\begin{tabular}{lcc}
\hline Variable & R Square & $\begin{array}{c}\text { R Square } \\
\text { Adjusted }\end{array}$ \\
\hline $\begin{array}{l}\text { STEM } \\
\text { Intention }\end{array}$ & .642 & .637 \\
Self-Efficacy & .393 & .372 \\
\hline
\end{tabular}

\section{DISCUSSION}

The present study attempted to understand the precursors of female participation in STEM education in Malaysia. For this purpose, the impact of five independent variables on self-efficacy was examined. These variables included attitude, selfconcept, gender stereotype, motivation, and teacher stereotypes. The impact of self-efficacy on intention to pursue STEM education was also examined. In addition, the direct and the moderating impact of career outcome expectancy was also examined on self-efficacy, as well as between self-efficacy and intention, respectively. The results showed that female attitude towards STEM subjects positively and significantly affects their STEM self-efficacy. The results are in congruence with prior research. In a study conducted on the relationship between self-efficacy and attitude towards computer technologies, Kinzie and Delcourt (1991) found that a positive attitude leads to positive self-efficacy. As mentioned earlier, the attitude of a person towards STEM affects their participation, interest (Greenfield, 1996), and achievement (Papanastasiou \& Zembylas, 2002).

The results for the impact of career outcome expectancy on female students' STEM self-efficacy are also in compliance with previous research. According to Maddux et al. (1982), and contrary to the popular narrative, a positive outcome expectancy may lead to incremented self-efficacy. According to SCCT, the career outcome expectations can increase the motivation of the person to pursue a particular career while overcoming the barriers and increasing her competency (Lent et al., 2002).

The results of the present study have shown that motivation positively and significantly predicts female STEM selfefficacy. Prior research has also indicated a positive relationship between motivation and self-efficacy. Husain (2014) pointed towards a strong relationship between both constructs. High motivation leads 
Table 7

Results for each hypothesis

\begin{tabular}{|c|c|c|}
\hline $\begin{array}{l}\text { Hypothesis } \\
\text { No. }\end{array}$ & Hypothesis Statement & Result \\
\hline H1 & $\begin{array}{l}\text { STEM self-concept will positively affect the STEM } \\
\text { self-efficacy of female students }\end{array}$ & Not supported \\
\hline $\mathrm{H} 2$ & $\begin{array}{l}\text { Attitude towards STEM will positively affect female } \\
\text { STEM self-efficacy. }\end{array}$ & Supported \\
\hline H3 & $\begin{array}{l}\text { STEM-related gender stereotypes will negatively } \\
\text { impact female students' STEM self-efficacy. }\end{array}$ & Supported \\
\hline H4 & $\begin{array}{c}\text { Motivation will positively impact female students' } \\
\text { STEM self-efficacy. }\end{array}$ & Supported \\
\hline H5 & $\begin{array}{c}\text { Teacher stereotypes will negatively impact female } \\
\text { students' STEM self-efficacy. }\end{array}$ & Supported \\
\hline H6 & $\begin{array}{l}\text { Self-efficacy will positively affect the intention of } \\
\text { women to pursue STEM education }\end{array}$ & Supported \\
\hline $\mathrm{H} 7$ & $\begin{array}{l}\text { COE will positively moderate the relationship } \\
\text { between female students' STEM self-efficacy and } \\
\text { intention to pursue STEM education. }\end{array}$ & Not supported \\
\hline
\end{tabular}

to the high achievement of goals which in turn leads to augmented self-efficacy (Ackerman, 2020). This present research found that gender stereotype affects female STEM self-efficacy negatively. As for the gender stereotypes, similar results were found by Cundiff et al. (2013), Schuster and Martiny (2017) as well as Garriott et al. (2017) that gender stereotypes negatively predict STEM-related self-efficacy. Due to gender stereotypes, female students face lifelong consequences in terms of lack of motivation and engagement in the STEM domain (McGuire et al., 2020). Similar to gender stereotypes, the results also found that teacher stereotypes also show negative effects on female STEM self-efficacy in a significant manner. Similar results were found by earlier research such as Blair et al. (2005), that teacher stereotypes can have a lasting and permanent impact on how females perceive their abilities in STEM. Teachers are one of the sources transmitting negative stereotypes on female lack of abilities in STEM subjects (Gunderson et al., 2012). Lavy and Sand (2015) argue further that teacher stereotypes also affect the intention of female students to take up STEM subjects in the future.

The results of the present research have shown a positive, significant, and strong impact of self-efficacy on female students' intentions to pursue STEM education. Brown et al (2016) also found similar results when examining the relationship between the self-efficacy and intention of middle school students. Similarly, Fouad and Santa (2017) found that a student's intent to pursue 
STEM education and goals is affected by self-efficacy. As for the impact of selfconcept on self-efficacy, the results showed that there is an insignificant relationship between both constructs. It is contrary to common belief and the results of the previous studies. It could be due to the small size of respondents and the coverage of data collected from only one state in Malaysia. The study also found that career outcome expectancy does not play a moderating role in the relationship between self-efficacy and the intention to pursue STEM education. It could be due to the context of the study which focused on secondary school students in Malaysia. For the female students at this level, career outcome expectancy may not be significant, as they may not comprehend the importance of a career at this early stage. Hence, this construct may not affect their intentions to pursue STEM education. Table 7 highlights the outcomes of the study for the hypotheses.

\section{CONCLUSION AND IMPLICATIONS}

The present research aimed to examine the impact of self-concept, attitude, motivation, and self-efficacy on individuals under study and contextual factors (i.e., gender and teacher stereotypes and career outcome expectancy) on the intention of female students to pursue STEM education in Malaysia. The study also aimed to propose a framework of individual and contextual factors affecting female participation in STEM education in Malaysia. Both objectives were achieved as discussed in the results and discussions sections of the paper. The impact of individual and contextual factors was examined thoroughly with the help of quantitative surveys and later by using the SmartPLS tool for statistical analysis.

The results of the study have many important implications. Firstly, the results of the study indicate that attitude, motivation, and career outcome expectancy are positive predictors of STEM-related self-efficacy among female students in Malaysia. The governments and policymakers can thus make policies to enhance the attitudes and motivation of female students. In addition, policies should be made to provide equal and safe opportunities for women to work in STEM-related careers.

Secondly, as the results of the study have shown that teacher and gender stereotypes are negative predictors of STEM-related self-efficacy among female students in Malaysia, steps to reduce these stereotypes can be taken to educate the masses as well as the teachers. Teachers can and should be trained to encourage female students to look positively at and get interested in STEM-related subjects. Moreover, female instructors for female students can also be one of the strategies to encourage students towards STEM education and careers.

Lastly, self-efficacy has proven to be a strong predictor of intention to pursue STEM education. Hence, it is important for the policymakers and the government to come up with policies to augment those factors which flourish and control those factors which may inhibit the STEM self- 
efficacy of Malaysian female students, as it will in turn increase their intentions to pursue STEM education.

The present study has some limitations. Firstly, the data was gathered from only two states of Malaysia including Selangor and Kuala Lumpur. Hence, one should be cautious to generalize the results of the study to the whole country. Further, the data was collected from only 211 secondary school female students in Form 4 and 5. It is important to enhance the scope of future studies by including more respondents from different levels of education. Female students from other states in Malaysia should also be included in the study. Furthermore, it is important to examine more variables in order to holistically understand the precursors of female participation in STEM education.

\section{ACKNOWLEDGEMENT}

We would like to acknowledge the funding provided by Universiti Tunku Abdul Rahman (UTAR), Malaysia for carrying out this research.

\section{REFERENCES}

Abdullah, K., Noor, N. M., \& Wok, S. (2008). The perceptions of women's roles and progress: A study of Malay women. Social Indicators Research, 89(3), 439-455. https://doi. org/10.1007/s11205-008-9242-7

Abu-Lail, N. I., Phang, F. A., Kranov, A. A., MohdYusof, K., Olsen, R. G., Letricewilliams, R., \& Abidin, A. Z. (2012, June 10-13). Persistent gender inequity in US undergraduate engineering: Looking to Jordan and Malaysia for factors to their success in achieving gender parity [Paper presentation]. 2012 ASEE Annual Conference \& Exposition, San Antonio, Texas. https://doi.org/10.18260/1-2--21793

Ackerman, E, C. (2020, December 21). What is self-efficacy theory in psychology? Positivepsychology.com. https:// positivepsychology.com/self-efficacy/

Ajzen, I. (1991). The theory of planned behavior. Organizational Behavior and Human Decision Processes, 50(2), 179-211. https://doi. org/10.1016/0749-5978(91)90020-t

Ambriz, J. (2016). Social cognitive career theory (SCCT) and Mexican/Mexican American youth career development, with a special focus on stem fields [Doctoral thesis, Washington State University]. http://hdl.handle.net/2376/12155

American Association of University Women. (2010). Why so few: Women in science, technology, engineering, and mathematics. Wellesley College Center for Research on Women.

Astin, H. S. (1975). Sex differences in mathematical and scientific precocity. The Journal of Special Education, 9(1), 79-91. https://doi. org/10.1177/002246697500900108

Azmawati, A. A., Endut, N., Hashim, I. H. M., Selamat, N. H., \& Ying, K. (2017). Negotiation with patriarchy in women's lives: A case study in a Malaysian public university. Journal of Business and Economics Review, 2(1), 28-35.

Bandura, A. (1977). Self-efficacy: The exercise of control. Freeman.

Bandura, A., Barbaranelli, C., Caprara, G., \& Postorelli, C. (2001). Self-efficacy beliefs as shapers of children's aspirations and career trajectories. Child Development, 72(1), 187206. https://doi.org/10.1111/1467-8624.00273

Blair, C., Gamson, D., Thorne, S., \& Baker, D. (2005). Rising mean IQ: Cognitive demand of mathematics education for young children, population exposure to formal schooling, and 
the neurobiology of the prefrontal cortex. Intelligence, 33(1), 93-106. https://doi. org/10.1016/j.intell.2004.07.008

Blakemore, J. E. O. (2003). Children's beliefs about violating gender norms: Boys shouldn't look like girls, and girls shouldn't act like boys. Sex roles, 48(9-10), 411-419.

Brown, P. L., Concannon, J. P., Marx, D., Donaldson, C., \& Black, A. (2016). An examination of middle school students' STEM self-efficacy, interests and perceptions. Journal of STEM Education: Innovations and Research, 17(3), 27-38.

Chubin, D. E., May, G. S., \& Babco, E. L. (2005). Diversifying the engineering workforce. Journal of Engineering Education, 94(1), 73-86. https:// doi.org/10.1002/j.2168-9830.2005.tb00830.x

Cundiff, J. L., Vescio, T. K., Loken, E., \& Lo, L. (2013). Do gender-science stereotypes predict science identification and science career aspirations among undergraduate science majors? Social Psychology of Education, 16(4), 541-554. https://doi.org/10.1007/s11218-0139232-8

Deci, E. L., \& Ryan, R. M. (2000). The" what" and" why" of goal pursuits: Human needs and the self-determination of behavior. Psychological Inquiry, 11(4), 227-268. https://doi.org/10.1207/ s15327965pli1104_01

Eccles, J. S. (1994). Understanding women's educational and occupational choices: Applying the Eccles et al. model of achievement-related choices. Psychology of Women Quarterly, 18(4), 585-609. https://doi. org/10.1111/j.1471-6402.1994.tb01049.x

Edzie, R. L. (2014). Exploring the factors that influence and motivate female students to enroll and persist in collegiate STEM degree programs: A mixed methods study [Doctoral dissertation, University of Nebraska]. https://digitalcommons. unl.edu/cgi/viewcontent.cgi?article $=1175 \&$ cont ext $=$ cehsedaddiss

Ertl, B., Luttenberger, S., \& Paechter, M. (2017). The impact of gender stereotypes on the self-concept of female students in STEM subjects with an under-representation of females. Frontiers in Psychology, 8, 703. https://doi.org/10.3389/ fpsyg.2017.00703

Fishbein, M., \& Ajzen, I. (1977). Belief, attitude, intention and behavior: An introduction to theory and research. Addison-Wiley Publishing Company. https://doi.org/10.2307/2065853

Fornell, C., \& Larcker, D. F. (1981). Evaluating structural equation models with unobservable variables and measurement error. Journal of Marketing Research, 18(1), 39-50. https://doi. org/10.1177/002224378101800104

García-Martín, J., \& García-Sánchez, J. N. (2020). The effectiveness of four instructional approaches used in a MOOC promoting personal skills for success in life. Revista de Psicodidáctica (English ed.), 25(1), 36-44. https://doi.org/10.1016/j. psicoe.2019.08.001

Garriott, P. O., Hultgren, K. M., \& Frazier, J. (2017). STEM stereotypes and high school students' math/science career goals. Journal of Career Assessment, 25(4), 585-600. https://doi. org/10.1177/1069072716665825

Goy, S. C., Wong, Y. L., Low, W. Y., Noor, S. N. M., Fazli-Khalaf, Z., Onyeneho, N., Daniel, E., Azizan, S., Hasbullah, M., \& GinikaUzoigwe, A. (2018). Swimming against the tide in STEM education and gender equality: A problem of recruitment or retention in Malaysia. Studies in Higher Education, 43(11), 1793-1809. https:// doi.org/10.1080/03075079.2016.1277383

Greenfield, T. A. (1996). Gender, ethnicity, science achievement, and attitudes. Journal of Research in Science Teaching: The Official Journal of the National Association 
for Research in Science Teaching, 33(8), 901-933. https://doi.org/10.1002/(sici)10982736(199610)33:8<901::aid-tea5>3.0.co;2-\#

Gunderson, E. A., Ramirez, G., Levine, S. C., \& Beilock, S. L. (2012). The role of parents and teachers in the development of gender-related math attitudes. Sex roles, 66(3), 153-166. https:// doi.org/10.1007/s11199-011-9996-2

Halim, L., Rahman, N. A., Ramli, N. A. M., \& Mohtar, L. E. (2018). Influence of students' STEM selfefficacy on STEM and physics career choice. AIP Conference Proceedings, 1923(1), 020001. https://doi.org/10.1063/1.5019490

Hardin, E. E., \& Longhurst, M. O. (2016). Understanding the gender gap: Social cognitive changes during an introductory stem course. Journal of Counseling Psychology, 63(2), 233. https://doi.org/10.1037/cou0000119

Henseler, J., Hubona, G., \& Ray, P. A. (2016). Using PLS path modeling in new technology research: Updated guidelines. Industrial Management \& Data Systems, 116(1), 2-20. https://doi. org/10.1108/imds-09-2015-0382

Henseler, J., Ringle, C. M., \& Sinkovics, R. R. (2009). The use of partial least squares path modeling in international marketing. Advances in International Marketing, 20(1), 277-319. https:// doi.org/10.1108/s1474-7979(2009)0000020014

Honey, M., Pearson, G., \& Schweingruber, H. (Eds). (2014). STEM integration in K-12 education: Status, prospects, and an agenda for research. National Academies Press. https://doi. org/10.17226/18612

Husain, U. K. (2014, December 10-11). Relationship between self-efficacy and academic motivation. International Conference on Economics, Education and Humanities (ICEEH'14), Bali, Indonesia. https://dx.doi.org/10.15242/ICEHM. ED1214132
Jenson, R. J., Petri, A. N., Day, A. D., Truman, K. Z., \& Duffy, K. (2011). Perceptions of self-efficacy among STEM students with disabilities. Journal of Postsecondary Education and Disability, 24(4), 269-283.

Kamsi, N. S., Firdaus, R. R., Razak, F. D. A., \& Siregar, M. R. (2019). Realizing Industry 4.0 through STEM education: But why STEM is not preferred? IOP Conference Series: Materials Science and Engineering, 506(1), 012005. https:// doi.org/10.1088/1757-899x/506/1/012005

Kinzie, M. B., \& Delcourt, M. A. (1991, April 3-7). Computer technologies in teacher education: The measurement of attitudes and self-efficacy [Paper presentation]. Annual Meeting of the American Educational Research Association, Chicago, USA.

Kulm, G. (1973, February 25 - March 1). A mathematics self-concept test. American Educational Research Association Meeting, New Orleans, Louisiana, USA.

Larose, S., Ratelle, C. F., Guay, F., Senécal, C., \& Harvey, M. (2006). Trajectories of science selfefficacy beliefs during the college transition and academic and vocational adjustment in science and technology programs. Educational Research and Evaluation, 12(4), 373-393. https://doi. org/10.1080/13803610600765836

Lavy, V., \& Sand, E. (2015). On the origins of gender human capital gaps: Short- and long-term consequences of teachers' stereotypical biases. National Bureau of Economic Research. https:// doi.org/10.3386/w20909

Leinhardt, G., Seewald, A. M., \& Engel, M. (1979). Learning what's taught: Sex differences in instruction. Journal of Educational Psychology, 71(4), 432-439. https://doi.org/10.1037/00220663.71 .4 .432

Lent, R. W., Brown, S. D., \& Hackett, G. (1994). Toward a unifying social cognitive theory 
of career and academic interest, choice, and performance. Journal of Vocational Behavior, 45(1), 79-122. https://doi.org/10.1006/ jvbe.1994.1027

Lent, R. W., Brown, S. D., \& Hackett, G. (2002). Social cognitive career theory. In Career choice and development (4th ed., pp. 255-311). John Wiley \& Sons, Inc.

Lent, R. W., Miller, M. J., Smith, P. E., Watford, B. A., Hui, K., \& Lim, R. H. (2015). Social cognitive model of adjustment to engineering majors: Longitudinal test across gender and race/ ethnicity. Journal of Vocational Behavior, 86, 77-85. https://doi.org/10.1016/j.jvb.2014.11.004

Maddux, J. E., Sherer, M., \& Rogers, R. W. (1982). Self-efficacy expectancy and outcome expectancy: Their relationship and their effects on behavioral intentions. Cognitive Therapy and Research, 6(2), 207-211.https://doi.org/10.1007/ bf01183893

Mahoney, M. P. (2010). Students' attitudes toward STEM: Development of an instrument for high school STEM-based programs. Journal of Technology Studies, 36(1), 24-34. https://doi. org/10.21061/jots.v36il.a.4

Marsh, H. W., \& Scalas, L. F. (2011). Selfconcept in learning: Reciprocal effects model between academic self-concept and academic achievement. Social and Emotional Aspects of Learning. In International Encyclopedia of Education (pp. 660-667). Elsevier Ltd. https:// doi.org/10.1016/b978-0-08-044894-7.00619-9

Martinez, A., \& Christnacht, C., (2021, January). Women making gains in STEM occupations but still underrepresented. United States Census Bureau. https://www.census.gov/library/ stories/2021/01/women-making-gains-instem-occupations-but-still-underrepresented. html\#: :text=Women\%20Are $\% 20$ Nearly $\% 20$ Half\%20 of,Only\%2027\%25\%20 of\%20
STEM $\% 20$ Workers\&text=Despite $\% 20$ making\%20up\%20nearly\%20half,and\%20 math\%20(STEM)\%20workforce

Maryann, N., \& Patience, A. C. (2017). Investigating factors influencing girls participation in science and technology education in Nigeria. Journal of Research \& Method in Education, 7(3), 50-54. https://doi.org/10.9790/7388-0703035054

McGuire, L., Mulvey, K. L., Goff, E., Irvin, M. J., Winterbottom, M., Fields, G. E., HartstoneRose, A., \& Rutland, A. (2020). STEM gender stereotypes from early childhood through adolescence at informal science centers. Journal of Applied Developmental Psychology, 67, 101109. https://doi.org/10.1016/j.appdev.2020.101109

Meng, C. C., Idris, N., \& Eu, L. K. (2014). Secondary students' perceptions of assessments in science, technology, engineering, and mathematics (STEM). Eurasia Journal of Mathematics, Science and Technology Education, 10(3), 219227. https://doi.org/10.12973/eurasia.2014.1070a

Moore, R., \& Burrus, J. (2019). Predicting STEM major and career intentions with the Theory of Planned Behavior. The Career Development Quarterly, 67(2), 139-155. https://doi. org/10.1002/cdq.12177

Mulvey, K. L., Hitti, A., \& Killen, M. (2010). The development of stereotyping and exclusion. Wiley Interdisciplinary Reviews: Cognitive Science, 1(4), 597-606. https://doi.org/10.1002/ wcs. 66

Noor, N. M. (2001). Work, family and well-being: Challenges of contemporary Malaysian women. IIUM Press.

Nugent, G., Barker, B., Welch, G., Grandgenett, N., Wu, C., \& Nelson, C. (2015). A model of factors contributing to STEM learning and career orientation. International Journal of Science Education, 37(7), 1067-1088. https://doi.org/10 $.1080 / 09500693.2015 .1017863$ 
O’Brien, L. T., Garcia, D. M., Blodorn, A., Adams, G., Hammer, E., \& Gravelin, C. (2020). An educational intervention to improve women's academic STEM outcomes: Divergent effects on well-represented vs. underrepresented minority women. Cultural Diversity and Ethnic Minority Psychology, 26(2), 163-168. https://doi. org/10.1037/cdp0000289

OECD. (2015). The ABC of gender equality in education: Aptitude, behaviour, confidence. OECD Publishing.

Osborne, J., Simon, S., \& Collins, S. (2003). Attitudes towards science: A review of the literature and its implications. International Journal of Science Education, 25(9), 1049-1079. https://doi.org/10. 1080/0950069032000032199

Pajares, F. (2004). Gender differences in mathematics self-efficacy beliefs. In A. M. Gallagher \& J. C. Kaufman (Eds.), Gender differences in mathematics: An integrative psychological approach (pp. 294-315). Cambridge University Press. https://doi.org/10.1017/ cbo9780511614446.015

Pang, V., Mun, H. C., \& Ompok, C. C. (2015, September 21-23). Early mathematics achievement of children in national government preschool in Tuaran District, Sabah: Do gender, types of preschool and duration in preschool matter? $1^{\text {st }}$ Borneo International Conference on Science and Mathematics Education, Sabah, Malaysia.

Papanastasiou, E. C., \& Zembylas, M. (2002). The effect of attitudes on science achievement: A study conducted among high school pupils in Cyprus. International Review of Education, 48(6), 469-484.

Rabenberg, T. A. (2013). Middle school girls' STEM education: Using teacher influences, parent encouragement, peer influences, and self efficacy to predict confidence and interest in math and science [Doctoral dissertation,
Drake University]. https://escholarshare.drake. edu/bitstream/handle/2092/2020/2013TARdd. pdf?seq

Rajenderan, M., \& Zawawi, D. (2019). Leaky pipeline syndrome in information and communication technology (ICT) industry of Malaysia: A conceptual study on female career barriers and retention management. International Journal of Academic Research in Business and Social Sciences, 9(2), 1158-1174. https://doi. org/10.6007/ijarbss/v9-i2/5672

Ramsey, C. M. (2018). STEM stories for STEM interest and identity for girls: A classroom-tested framework and prototype [Doctoral dissertation, The University of Texas at Austin]. https:// repositories.lib.utexas.edu/handle/2152/72750

Renno, M. P., \& Shutts, K. (2015). Children's social category-based giving and its correlates: Expectations and preferences. Developmental Psychology, 51(4), 533-543. https://doi. org/10.1037/a0038819

Riegle-Crumb, C., Moore, C., \& Ramos-Wada, A. (2011). Who wants to have a career in science or math? Exploring adolescents' future aspirations by gender and race/ethnicity. Science Education, 95(3), 458-476. https://doi.org/10.1002/ sce. 20431

Rittmayer, A. D., \& Beier, M. E. (2008). Overview: Self-efficacy in STEM. SWE-AWE CASEE Overviews, 1-12.

Ruble, D. N., Martin, C. L., \& Berenbaum, S. A. (2007). Gender development. In Handbook of child psychology (Vol. 3). John Wiley \& Sons, Inc. https://doi.org/10.1002/9780470147658. chpsy0314

Sahranavard, M., \& Hassan, S. (2012). The relationship between self-concept, self-efficacy, self-esteem, anxiety and science performance among Iranian students. Middle East Journal of Scientific Research, 12(9), 1190-1196. 
Sajid, S., Alam, M. S., Kok, J. K., \& Rehman, M. (2020). Women's participation in Science, Technology Engineering and Mathematics (STEM) education: A review of literature. Asia Proceedings of Social Sciences, 6(3), 230-234.

Salleh, S.M. (2013). Factors Influencing Students' Intentions to Study Science in Upper Secondary. International Journal for Cross-Disciplinary Subjects in Education, 4, 1158-1165. https://doi.org/10.20533/ ijcdse.2042.6364.2013.0163

Schuster, C., \& Martiny, S. E. (2017). Not feeling good in STEM: Effects of stereotype activation and anticipated effect on women's career aspirations. Sex Roles, 76(1-2), 40-55. https:// doi.org/10.1007/s11199-016-0665-3

Springer, S. H., Larson, L. M., Tilley, B. P., Gasser, C. E., \& Quinn, A. C. (2001, August 24-28). The development of an educational and career outcome expectancy scale (Paper presentation). Annual Meeting of the American Psychological Association, San Francisco, USA.

Swarat, S., Ortony, A., \& Revelle, W. (2012). Activity matters: Understanding student interest in school science. Journal of Research in Science Teaching, 49(4), 515-537. https://doi. org/10.1002/tea.21010
The Association of Academies and Societies of Sciences in Asia. (2014). Women in science and technology in Asia. http://aassa.asia/ achievements/achievements.php?bbs_data $=\mathrm{aW}$ R4PTgwJnN0YXJ0UGFnZT0wJmxpc3RObz 0mdGFibGU9Y3NfYmJzX2RhdGEmY29kZT 1hY2hpZXZlbWVudCZzZWFyY2hfaXRlbT0 me2VhemNoX29yZGVyPQ==\%7C\%7C\&bgu =view

United Nations Educational, Scientific and Cultural Organization. (2017). Cracking the code: Girls' and women's education in Science, Technology, Engineering and Mathematics (STEM). http://unesdoc.unesco.org/ images/0025/002505/250567e.pdf

Wang, M. T., \& Eccles, J. S. (2012). Social support matters: Longitudinal effects of social support on three dimensions of school engagement from middle to high school. Child Development, 83(3), 877-895. https://doi.org/10.1111/j.14678624.2012.01745.x

Yeoh, M. P., \& Ierardi, E. (2015). Motivation and achievement of Malaysian students in studying matriculation Biology. International Journal of Advanced Research, 3(11), 966-978. 


\section{APPENDIX}

Appendix 1

Questionnaire

STEM Self-Concept (Kulm, 1973)

\begin{tabular}{|c|c|}
\hline Item & Coding \\
\hline How good a student am I in STEM subjects? & $\mathrm{SC} 1$ \\
\hline How much am I learning in STEM subjects? & $\mathrm{SC} 2$ \\
\hline How comfortable do I feel in STEM subjects' classes? & $\mathrm{SC} 3$ \\
\hline How often do I take part in class discussions? & $\mathrm{SC} 4$ \\
\hline $\begin{array}{l}\text { How well do I stick to STEM subjects' problems without giving } \\
\text { up? }\end{array}$ & $\mathrm{SC} 5$ \\
\hline How well do I remember what I learn in STEM subjects? & SC6 \\
\hline How often do I volunteer in STEM subjects' class? & $\mathrm{SC} 7$ \\
\hline How well do I do on STEM subjects quizzes? & SC8 \\
\hline How often do I ask questions when I don't understand? & SC9 \\
\hline How often do I do assignments on time? & $\mathrm{SC} 10$ \\
\hline How many good ideas do I have in STEM subjects' class? & SC11 \\
\hline How well am I doing compared to others in class? & $\mathrm{SC} 12$ \\
\hline How well am I able to concentrate on STEM subjects? & $\mathrm{SC} 13$ \\
\hline How much do I enjoy myself in STEM subjects' class? & $\mathrm{SC} 14$ \\
\hline How much do I like STEM subjects? & $\mathrm{SC} 15$ \\
\hline How much attention do I pay in STEM subjects' class? & $\mathrm{SC} 16$ \\
\hline How easily do I learn STEM subjects? & $\mathrm{SC} 17$ \\
\hline How often do I go ahead with problems on my own? & SC18 \\
\hline How well do I understand STEM content in class? & SC19 \\
\hline How well am I able to apply what I learn? & $\mathrm{SC} 20$ \\
\hline How often do I get homework problems done correctly? & $\mathrm{SC} 21$ \\
\hline How calm do I feel when called on in class? & $\mathrm{SC} 22$ \\
\hline How confident am I that I can learn STEM subjects? & $\mathrm{SC} 23$ \\
\hline How interested am I in STEM subjects? & $\mathrm{SC} 24$ \\
\hline How well do I keep up with assignments? & $\mathrm{SC} 25$ \\
\hline How little do I worry about tests in STEM subjects? & $\mathrm{SC} 26$ \\
\hline How much do I care about learning STEM subjects? & $\mathrm{SC} 27$ \\
\hline
\end{tabular}




\section{Attitude towards STEM (Mahoney, 2010)}

\begin{tabular}{lc}
\hline Item & Coding \\
\hline I do not like STEM subjects. & ATT1 \\
I enjoy learning about STEM subjects. & ATT 2 \\
I am curious about STEM subjects. & ATT 3 \\
I am not interested in STEM subjects. & ATT 4 \\
I like STEM subjects. & ATT 5 \\
STEM subjects are appealing to me. & ATT 6 \\
STEM subjects are difficult for me. & ATT 7 \\
I do well in STEM subjects. & ATT 8 \\
I am not confident about my work in STEM subjects. & ATT 9 \\
I have a hard time in STEM subjects. & ATT 10 \\
Assigned work in STEM subjects is easy for me. & ATT 11 \\
I cannot figure out STEM subjects. & ATT 12 \\
STEM subjects are important to me. & ATT 13 \\
I feel there is a need for STEM subjects. & ATT 14 \\
I do not need STEM subjects. & ATT 15 \\
It is valuable for me to learn STEM subjects. & ATT 16 \\
STEM subjects are good for me. & ATT 17 \\
I do not care about STEM subjects. & ATT 18 \\
I will continue to enjoy STEM subjects. & ATT 19 \\
I am not interested in a career involving STEM subjects. & ATT 20 \\
I am interested in alternative programs in STEM subjects. & ATT 21 \\
I would like to learn more about STEM subjects & ATT 22 \\
I do not wish to continue my education STEM subjects. & ATT 23 \\
I am committed to learning STEM subjects. & ATT 24 \\
\hline
\end{tabular}


Gender Stereotypes (Maryann and Patience, 2017)

\begin{tabular}{|c|c|}
\hline Item & Coding \\
\hline Girls are assigned more domestic duties in the house than boys. & GS1 \\
\hline Girls do not have adequate time to study in the house. & GS2 \\
\hline $\begin{array}{l}\text { My parents advise me not to choose science and technology courses } \\
\text { for my future career. }\end{array}$ & GS 3 \\
\hline $\begin{array}{l}\text { I do not get enough support from my parents to tackle problems in } \\
\text { science and technology. }\end{array}$ & GS 4 \\
\hline $\begin{array}{l}\text { Science and technology teachers do not encourage girls to aspire for } \\
\text { science and technology careers. }\end{array}$ & GS 5 \\
\hline $\begin{array}{l}\text { Girls are usually intimidated in the class by boys when girls } \\
\text { perform better in science and technology courses. }\end{array}$ & GS 6 \\
\hline $\begin{array}{l}\text { Science and technology teachers ask boys questions more often } \\
\text { than girls in the class. }\end{array}$ & GS 7 \\
\hline $\begin{array}{l}\text { I am not free to express my opinions in the science class without } \\
\text { fear of ridicule from the boys. }\end{array}$ & GS 8 \\
\hline $\begin{array}{l}\text { The science teacher acknowledges, encourages and motivates boys } \\
\text { more than girls. }\end{array}$ & GS 9 \\
\hline $\begin{array}{l}\text { In my society, girls are brought up with the notion that the study of } \\
\text { science and technology are for boys and tough girls. }\end{array}$ & GS 10 \\
\hline $\begin{array}{l}\text { In my culture, women are regarded as weak and incapable of } \\
\text { aspiring for challenging courses like science and technology. }\end{array}$ & GS11 \\
\hline $\begin{array}{l}\text { Women in science and technology are seen as rebellious and too } \\
\text { strong for men to marry. }\end{array}$ & GS12 \\
\hline Female models are seldom seen in science and technology. & GS13 \\
\hline $\begin{array}{l}\text { Many important scientists in my country are males, so this means } \\
\text { science and technology courses are mainly for males. }\end{array}$ & GS14 \\
\hline I see science and technology courses as male subjects. & GS15 \\
\hline $\begin{array}{l}\text { Girls feel discouraged and often tend to admit that boys are better } \\
\text { than girls in science and technology courses. }\end{array}$ & GS16 \\
\hline $\begin{array}{l}\text { Girls believe they cannot study engineering or mathematics or any } \\
\text { technology course. }\end{array}$ & GS17 \\
\hline $\begin{array}{l}\text { Girls are weaker than boys and so cannot do tough courses in } \\
\text { science and technology. }\end{array}$ & GS18 \\
\hline I think the only science subject a woman can do well in is Biology. & GS19 \\
\hline
\end{tabular}


Motivation (Edzie, 2014)

\begin{tabular}{lc}
\hline Item & Coding \\
\hline I enjoy mathematics. & MT1 \\
I enjoy science. & MT2 \\
I see great career opportunities in STEM. & MT3 \\
I have strong desire to pursue Science and engineering. & MT4 \\
My mother works in a STEM field & MT5 \\
My father works in a STEM field. & MT6 \\
My school counselor encouraged me to take up STEM subjects. & MT7 \\
I want to help others. & MT8 \\
My high school teacher encouraged me. & MT9 \\
I think that there are great salary opportunities in the STEM field. & MT10 \\
\hline
\end{tabular}

\section{Self-Efficacy (Jenson et al, 2011)}

How confident are you that you can...

\section{Item}

\section{Coding}

Get good grades in your STEM courses this semester?

SE1

SE2

SE3

SE4

SE5

SE6

Remain calm and relaxed during tests?

SE7

Remain calm and relaxed when expected to complete a challenging assignment?

\begin{tabular}{lc}
\hline Teacher Stereotypes (Ertl, Luttenberger, \& Paechter, 2017) & Coding \\
\hline Item & TS1 \\
\hline $\begin{array}{l}\text { Teachers are more likely to encourage boys to take STEM } \\
\text { subjects. }\end{array}$ & TS2 \\
$\begin{array}{l}\text { Teachers are more likely to encourage girls to take STEM } \\
\text { subjects. }\end{array}$ & TS3 \\
$\begin{array}{l}\text { Teachers are more likely to discourage boys to take STEM } \\
\text { subjects. }\end{array}$ & TS4 \\
$\begin{array}{l}\text { Teachers are more likely to discourage girls to take STEM } \\
\text { subjects. }\end{array}$ & \\
\hline
\end{tabular}




\section{Intention (Salleh , 2013)}

\begin{tabular}{lc}
\hline Item & Coding \\
\hline I will take up STEM subjects in Upper Secondary level. & IN1 \\
I will learn STEM subjects to get a job. & IN2 \\
I will learn STEM subjects to gain more scientific knowledge. & IN3 \\
$\begin{array}{l}\text { I will learn STEM subjects if I get good grades in science } \\
\text { examination. }\end{array}$ & IN4 \\
\hline
\end{tabular}

\section{Career Outcome Expectancy (Springer et al., 2001)}

\begin{tabular}{|c|c|}
\hline Item & Coding \\
\hline $\begin{array}{l}\text { If I pursue a STEM-related career, I will get a feeling of } \\
\text { accomplishment, }\end{array}$ & COE1 \\
\hline $\begin{array}{l}\text { If I pursue a STEM-related career, I will be somebody special } \\
\text { in the job, }\end{array}$ & COE2 \\
\hline $\begin{array}{l}\text { If I pursue a STEM-related career, it will be easy to make } \\
\text { friends with people at my place of employment. }\end{array}$ & COE3 \\
\hline $\begin{array}{l}\text { If I pursue a STEM-related career, I will get recognition/ } \\
\text { praise for the things I do. }\end{array}$ & COE4 \\
\hline $\begin{array}{l}\text { If I in pursue a STEM-related career, I will do something that } \\
\text { makes full use of my abilities. }\end{array}$ & COE5 \\
\hline $\begin{array}{l}\text { If I pursue a STEM-related career, my supervisor will } \\
\text { communicate his/her expectations well. }\end{array}$ & COE6 \\
\hline $\begin{array}{l}\text { If I work in a STEM related workplace, I will have good } \\
\text { working conditions. }\end{array}$ & COE7 \\
\hline $\begin{array}{l}\text { If I pursue a STEM-related career, I will have an opportunity } \\
\text { for self-advancement. }\end{array}$ & COE8 \\
\hline $\begin{array}{l}\text { If I pursue a STEM related career, I will be able to try out my } \\
\text { own ideas. }\end{array}$ & COE9 \\
\hline $\begin{array}{l}\text { If I pursue a STEM-related career, I will be able to make } \\
\text { decisions on my own. }\end{array}$ & COE10 \\
\hline $\begin{array}{l}\text { If I get a job in an STEM-related career, the employers will } \\
\text { provide for my continuing employment. }\end{array}$ & COE11 \\
\hline $\begin{array}{l}\text { If I get a job in an STEM-related career, my supervisor/boss } \\
\text { will back me up. }\end{array}$ & COE12 \\
\hline
\end{tabular}




\begin{tabular}{ll}
\hline Item & Coding \\
\hline $\begin{array}{l}\text { If I pursue a STEM-related career, people of my ethnic origin } \\
\text { will be accepted and will have good job possibilities. }\end{array}$ & COE13 \\
$\begin{array}{l}\text { If I pursue a STEM-related career, I will do something } \\
\text { different every day. }\end{array}$ & COE14 \\
$\begin{array}{l}\text { If I work get a job in an STEM-related career, I will do things } \\
\text { for other people }\end{array}$ & COE15 \\
$\begin{array}{l}\text { If I pursue a STEM-related career, my salary will be } \\
\text { comparatively better compared to others. }\end{array}$ & COE16 \\
$\begin{array}{l}\text { If I pursue a STEM-related career I will not be bored. } \\
\text { If I get a job in a STEM-related career, my work hours will be } \\
\text { flexible to meet the needs of the family. }\end{array}$ & COE17 \\
$\begin{array}{l}\text { If I pursue a STEM-related career, I will direct other people's } \\
\text { activities. }\end{array}$ & COE18 \\
$\begin{array}{l}\text { If I pursue a STEM related career, I will be able to work } \\
\text { independently. }\end{array}$ & COE19 \\
$\begin{array}{l}\text { If I pursue a STEM related career, I will not be required to act } \\
\text { in ways that are morally wrong. }\end{array}$ & COE20 \\
$\begin{array}{l}\text { Careers in STEM are not family friendly. } \\
\text { Careers in STEM are not in line with the traditional role of } \\
\text { women. }\end{array}$ & COE21 \\
Workplaces in STEM are not very women- friendly. & COE22 \\
\hline
\end{tabular}


